\title{
Effect of thrombin inhibition on synovial inflammation in antigen induced arthritis
}

Pierre Alain Varisco, Veronique Péclat, Karen van Ness, Angelika Bischof-Delaloye, Alexander So, Nathalie Busso

\begin{abstract}
Objective-To determine the effect of the thrombin inhibitor, hirudin, on the pathogenesis of murine antigen induced arthritis (AIA).

Methods-AIA was induced by intraarticular injection of methylated bovine serum albumin in the knee joints of previously immunised mice. Hirudin (injected subcutaneously $3 \times 200 \mu \mathrm{g} / \mathrm{mouse} /$ day) was given over 13 days, starting three days before arthritis onset, and its anticoagulant effect monitored by clotting times. Arthritis severity was evaluated by technetium-99m $\left({ }^{99 \mathrm{~m}} \mathrm{Tc}\right)$ uptake in the knee joints and by histological scoring. In addition, intra-articular fibrin deposition was examined by immunohistochemistry, and synovial cytokine mRNA expression measured by RNase protection.

Results-Joint inflammation, measured by ${ }^{99 m}$ Tc uptake, was significantly reduced in hirudin treated mice at days 7 and 10 after arthritis onset. Histologically, synovial thickness was markedly decreased in hirudin treated mice compared with untreated ones. By contrast, no difference in articular cartilage proteoglycan content was found between both groups. Intraarticular fibrin deposition and synovial interleukin $1 \beta \mathrm{mRNA}$ levels, were slightly reduced $(\sim 20 \%)$ in arthritic joints from hirudin treated mice compared with untreated ones at day 10 of AIA.

Conclusion-Hirudin reduces joint inflammation associated with AIA by fibrindependent and independent mechanisms. (Ann Rheum Dis 2000;59:781-787)
\end{abstract}

Rheumatoid arthritis (RA) is a chronic systemic inflammatory disease characterised by synovial inflammation and hyperplasia, leading to progressive cartilage and bone destruction. ${ }^{1}$ Although immunological processes clearly play a part in RA, they do not account for all the features of chronic inflammation found in rheumatoid joints, in particular for the abundant fibrin deposits in RA synovia. ${ }^{23}$

The formation of extravascular fibrin within the arthritic joints probably results from activation of the coagulation pathway during inflammation. ${ }^{4}$ Increased permeability of the inflamed synovial microvasculature leads to extravasation of plasma fibrinogen. This latter could be rapidly converted to fibrin by thrombin, formed through activation of the tissue factor mediated coagulation pathway. Besides fibrin deposition, evidence for in- creased extravascular coagulation within the rheumatoid joint includes the demonstration of an intact coagulation pathway within the rheumatoid synovium and, in particular, the existence of increased expression of the tissue factor and thrombin. ${ }^{35}$ Moreover, in RA synovial fluids, reduced levels of coagulation factors with concomitantly increased concentrations of thrombin activity and thrombin-antithrombin (TAT) complexes have been found, suggesting continuing coagulation. ${ }^{67}$ The persistence of fibrin in the inflamed joint may have deleterious effects. ${ }^{8-14}$ As intra-articular fibrin reflects the balance between local fibrinolysis and coagulation, we proposed that efficient fibrinolysis or reduced coagulation, or both, are necessary for the resolution of arthritis. For fibrinolysis, we have shown that in mice which were deficient in urokinase-type plasminogen activator or plasminogen, arthritis was excacerbated, but this excacerbation was attenuated by defibrinogenation with ancrod. ${ }^{15}$ Taken together, these results emphasise the linkage between inflammation and fibrin deposition in arthritis.

Another important player in the coagulation cascade, which also sustains inflammation, seems to be thrombin. Besides its well known activity in the coagulation pathway, thrombin generation in the joint may also affect synovial cell proliferation and inflammatory cell recruitment during arthritis. ${ }^{16}$ These effects are independent of the formation of fibrin, and are mediated through the cell surface thrombin receptor PAR-1 (protease activated receptor 1). PAR-1 is a member of the family of G coupled proteins with seven transmembrane domains. ${ }^{17}$ This multifunctional receptor is activated by proteolytic cleavage of an $\mathrm{N}$-terminus extramembrane fragment by thrombin such that the newly created $\mathrm{N}$-terminus can then act as a "tethered ligand", leading to receptor activation. ${ }^{17}$

In light of these results we wished to determine if inhibition of thrombin may be therapeutic in experimental arthritis. Hirudin, a highly specific thrombin inhibitor, inhibits thrombin activity directly by non-covalent binding to the substrate recognition and catalytic binding sites of the enzyme. ${ }^{18}{ }^{19}$ Hirudin itself is a naturally occurring molecule produced by the salivary glands of the leech, Hirudo medicinalis, but in clinical studies a number of synthetic hirudin derivatives have been used. Lepirudin, the recombinant hirudin which was employed in this study, has already been used in the treatment of heparin induced thrombocytopenia, deep vein thrombosis, and 
coronary vascular disease in man. ${ }^{20}$ We studied here the effect of hirudin treatment on antigen induced arthritis (AIA).

\section{Materials and methods}

INDUCTION OF ARTHRITIS

Antigen induced arthritis in $\mathrm{C} 57 \mathrm{Bl} / 6$ mice (Iffa-Credo, L'Arbresle, France) was established as previously described. ${ }^{21}$ Briefly, mice were immunised at days 0 and 7 with $100 \mu \mathrm{g}$ methylated bovine serum albumin (mBSA; Sigma Chemical Company, Buchs, Switzerland) emulsified in $0.1 \mathrm{ml}$ complete Freund's adjuvant containing $200 \mu \mathrm{g}$ mycobacterial strain H37RA (Difco, Basel, Switzerland) by intradermal injection at the base of tail. On the same days, $2 \times 10^{9}$ heat killed Bordetella pertussis organisms (Berna, Bern, Switzerland) were injected intraperitoneally as an additional adjuvant. Arthritis was induced at day 21 by intra-articular injection of $100 \mu \mathrm{g}$ of mBSA in $10 \mu \mathrm{l}$ sterile phosphate buffered saline (PBS) into the right knee, the left knee being injected with sterile PBS alone. Institutional approval was obtained for these experiments.

ISOTOPIC QUANTIFICATION OF JOINT

INFLAMMATION

Joint inflammation was measured by uptake in the knee joint as described. ${ }^{22}$ Briefly, mice were first anaesthetised by methoxyflurane and then injected subcutaneously in the neck region with $10 \mu \mathrm{Ci}{ }^{99 \mathrm{~m}} \mathrm{Tc}$. The accumulation of the isotope in the knee was determined by external gamma counting after 15 minutes. The ratio of ${ }_{99 \mathrm{~m}} \mathrm{Tc}$ uptake in the inflamed arthritic knee to ${ }^{99 m}$ Tc uptake in the contralateral control knee was calculated. A ratio higher than 1.1 indicated joint inflammation.

HISTOLOGICAL GRADING OF ARTHRITIS

At least 10 mice in each group were killed, the knees dissected, and fixed in $10 \%$ buffered formalin for seven days. Fixed tissues were decalcified for three weeks in 15\% EDTA, dehydrated, and embedded in paraffin. Sagittal sections $(8 \mu \mathrm{m})$ of the whole knee joint were stained with safranin $\mathrm{O}$ and counterstained with fast green/iron haematoxylin. Histological sections were graded independently by two observers unaware of the animal treatment using the following measures. Synovial membrane thickness was scored on a scale of $0-3(0$ $=$ normal thickness to $3=$ maximum thickness). Cartilage proteoglycan depletion, reflected by loss of safranin $\mathrm{O}$ staining intensity, was scored on a scale of 0 (fully stained cartilage) to 3 (totally unstained cartilage) in proportion to severity. For each histopathological measure the score (mean(SEM)) of all slides was calculated.

\section{FIBRIN IMMUNOHISTOCHEMISTRY}

Paraffin embedded sections were deparaffinised and rehydrated, then incubated for 30 minutes at room temperature with 5\% BSA and 20\% normal goat serum. Endogenous peroxidase activity was blocked with $3 \% \mathrm{H}_{2} \mathrm{O}_{2}$ for 10 minutes. Slides were then overlayed with rabbit antimouse fibrinogen serum (diluted 1/1000) for 30 minutes at room temperature. Bound antibody was visualised using the avidin-biotinperoxidase complex (Vectastain Elite ABC kit, Vector Laboratories, Burlingame, CA, USA). The colour was developed by 3,3'diaminobenzidine (Sigma Chemical Company) containing $0.01 \% \mathrm{H}_{2} \mathrm{O}_{2}$. After extensive washing in water, slides were counterstained with $\mathrm{Pa}$ panicolaou and mounted in Merckoglass. Staining specificity was confirmed using, as primary antibodies, non-immune rabbit serum or fibrinogen preadsorbed immune serum. An incubation without the first antibody served as a negative control. Fibrin immunostaining in the synovial membrane was graded independently by two observers unaware of the animal treatment on a scale of 0 (no fibrin at all) to 6 (maximum fibrin staining).

ANTICOAGULATION WITH HIRUDIN

(Leu1,Thr2)-63-desulphohirudin (Refludan, Hoechst Marion Roussel SA, Zurich, Switzerland) was used. The solution was reconstituted from the supplied powder in a concentration of $200 \mu \mathrm{g} / 100 \mu \mathrm{l}$ with $0.9 \% \mathrm{NaCl}$. The reconstituted solution is stable for 24 hours at room temperature. The mice were injected subcutaneously with $100 \mu \mathrm{l}$ of this solution three times a day, every eight hours. The treatment lasted 13 days, starting three days before induction of arthritis and during the 10 days of AIA. PBS injected mice were used as controls.

\section{CLOTTING TIMES}

To obtain plasma, blood was collected from the tail vein or from the inferior vena cava in anaesthetised animals in $0.12 \mathrm{M}$ trisodium citrate (one volume of citrate to nine volumes of blood). Blood samples were centrifuged at $1500 \mathrm{~g}$ for 15 minutes at $4^{\circ} \mathrm{C}$ and plasmas stored at $-20^{\circ} \mathrm{C}$ until used. All clotting times, performed on citrated plasma diluted in Owren's buffer (sodium diethylbarbiturate buffer $\mathrm{pH}$ 7.35) prewarmed at $37^{\circ} \mathrm{C}$, were obtained with an Amelung microcoagulometer (Dialine, Itingen, Switzerland). For determination of the prothrombin time (PT) $50 \mu \mathrm{l}$ of fivefold diluted plasma was used. After addition of $100 \mu \mathrm{l}$ of a thromboplastin reagent (Recombiplastin Ortho, Almedica, Galmiz, Switzerland), time to thrombus formation was recorded. For activated partial thrombin time (aPTT) $50 \mu \mathrm{l}$ of a twofold diluted plasma was incubated with $50 \mu \mathrm{l}$ of activated cephalin reagent (Actin, Dade-Behring, Düdingen, Switzerland) for two minutes at $37^{\circ} \mathrm{C}$. After addition of $50 \mu \mathrm{l}$ of $0.025 \mathrm{M} \mathrm{CaCl}_{2}$, time to thrombus formation was recorded. For thrombin time (TT) measurement, $50 \mu \mathrm{l}$ of twofold diluted plasma was used. After addition of $50 \mu \mathrm{l}$ of a twofold diluted thrombin reagent (Thromboclotin, Dade-Behring, Düdingen, Switzerland), time to thrombus formation was recorded.

\section{THROMBIN-ANTITHROMBIN III (TAT)} DETERMINATIONS

TAT complex concentration in plasma was measured by a commercially available enzyme linked immunosorbent assay (ELISA) kit 
Table 1 Coagulation times and plasma thrombin-antithrombin (TAT) levels of hirudin treated mice with antigen induced arthritis (AIA). Activated partial thrombin time (aPTT), thrombin time (TT), prothrombin time (PT), and plasma TAT levels were measured in untreated and hirudin treated mice with AIA, 10 days after arthritis onset. Citrated plasmas were prepared from blood collected $1.5 \mathrm{~h}, 3 \mathrm{~h}$, and $5 \mathrm{~h}$ after the last subcutaneous injection of hirudin. Results are expressed as means (SEM)

\begin{tabular}{|c|c|c|c|c|c|c|c|c|}
\hline \multirow[b]{2}{*}{ Mice with AIA } & \multicolumn{2}{|l|}{$a P T T(s)$} & \multicolumn{2}{|c|}{ Thrombin time (s) } & \multicolumn{2}{|c|}{ Prothrombin time (s) } & \multicolumn{2}{|c|}{ Plasma TAT (ng/ml) } \\
\hline & $36.7(1.3)$ & $\mathrm{n}=9$ & $27.3(0.6)$ & $\mathrm{n}=9$ & $12.9(0.4)$ & $\mathrm{n}=9$ & $8.38(108)$ & $\mathrm{n}=8$ \\
\hline \multicolumn{9}{|l|}{ Mice with AIA + hirudin: } \\
\hline $1.5 \mathrm{~h}$ after last injection & $116.1(6.1)$ & $\mathrm{n}=3+$ & $>250(0)$ & $\mathrm{n}=3+$ & $14.3(0.5)$ & $\mathrm{n}=10$ & $2.03(0.65)$ & $n=3^{\star}$ \\
\hline $3 \mathrm{~h}$ after last injection & $54.6(5.5)$ & $n=3 \dagger$ & $217.9(32.1)$ & $n=3 \dagger$ & & & $3.99(0.84)$ & $\mathrm{n}=3$ \\
\hline $5 \mathrm{~h}$ after last injection & $36.1(1.1)$ & $\mathrm{n}=3$ & $28.4(0.8)$ & $\mathrm{n}=3$ & & & $4.94(0.96)$ & $\mathrm{n}=3$ \\
\hline
\end{tabular}

Statistical significance was tested by Student's $t$ test: ${ }^{\star} \mathrm{p}<0.05 ; \mathrm{tp}<0.01$.

designed for human TAT (Enzygnost TAT, Dade-Behring, Marburg, Germany), which cross reacts also with murine TAT. The content of murine TAT in plasma was calculated according to the human TAT standard curve.

ANTI-BSA ANTIBODIES MEASUREMENT

Ninety six well plates were coated for two hours with $1 \%$ BSA in PBS. Plasma $(100 \mu \mathrm{l})$, serially diluted in $\mathrm{PBS} / 1 \%$ gelatin (final dilutions $1 / 50$, $1 / 100,1 / 200,1 / 400$ ) was incubated for two hours at room temperature. Wells were washed four times with TTBS (50 mM Tris $\mathrm{pH} 7.4,140$ $\mathrm{mM} \mathrm{NaCl}$, containing $0.05 \%$ Tween 20 ). Then, $100 \mu \mathrm{l} /$ well of alkaline phosphatase conjugated antimouse IgG (Sigma Chemical Company) diluted 1/500 in TTBS was added. After four washings with TTBS, colour was developed with $100 \mu \mathrm{l} /$ well of $p$-nitrophenylphosphate (Sigma Chemical Company) and the reaction stopped by adding $25 \mu \mathrm{l} /$ well of $3 \mathrm{M} \mathrm{NaOH}$. Plate reading was performed at $405 \mathrm{~nm}$, and the resuts expressed as the percentage of absorbance units of control mice.

\section{RNASE PROTECTION ASSAY}

Total RNA was extracted from cryostat sections of synovial tissues from knee joints using the Trizol reagent (Gibco BRL, Switzerland).

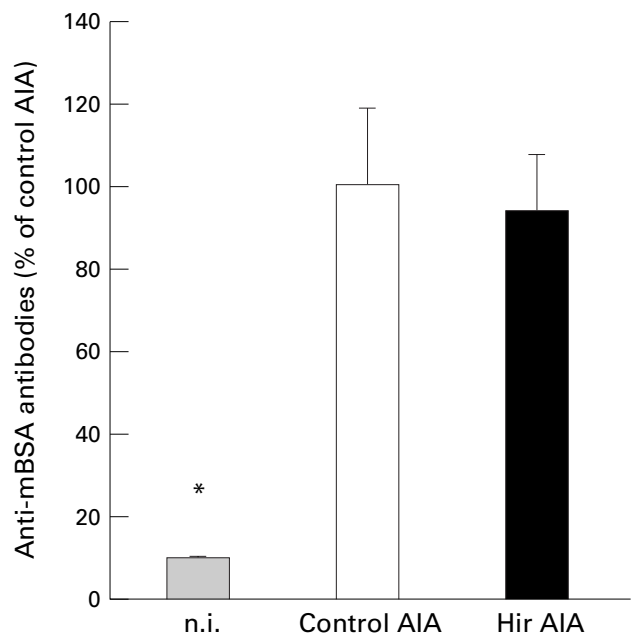

Figure 1 Anti-methylated bovine serum albumin (anti-mBSA) antibody levels in control and hirudin treated mice with antigen induced arthritis $(A I A)$. The results were expressed as a percentage of the anti-mBSA antibody content in the plasma of untreated arthritic mice. There was no significant difference between immunisations in untreated $(n=11)$ and treated $(n=12)$ arthritic mice. Non-immunised (n.i.), non-arthritic mice $(n=5)$, were used as negative controls. Results are expressed as means (SEM). Statistical significance was tested by Student's $t$ test. ${ }^{*} p<0.05$ was considered significant.
RNase protection assay was performed with the mCK-2 mutiprobe set (Pharmingen, Basel, Switzerland), according to the manufacturer's instructions. Briefly, antisense $\alpha\left[{ }^{32} \mathrm{P}\right] \mathrm{UTP}$ labelled riboprobes were synthesised by in vitro transcription of the mCK-2 DNA template set. DNase I treatment was performed to remove the DNA templates and riboprobes were purified by phenol/chloroform extraction, followed by ethanol precipitation with glycogen as carrier. For each sample about $5 \mu \mathrm{g}$ of total RNA was hybridised overnight at $52^{\circ} \mathrm{C}$ with $3 \times 10^{5} \mathrm{cpm}$ of the labelled multiprobe. Samples were first treated with an RNase cocktail (Ambion), then $\mathrm{RNase}$ was removed by proteinase $\mathrm{K}$ treatment, and samples purified by phenol/chloroform extraction, followed by ethanol precipitation with glycogen as carrier. Protected fragments were resolved through a 5\% sequencing gel. Precise quantification was determined by analysing the gel with an InstantImager apparatus and software (Packard Instruments). For each protected band analysed, a $\mathrm{cpm} / \mathrm{mm}^{2}$ value was obtained. This value was corrected for sample loading errors by normalising with the respective $\mathrm{cpm} / \mathrm{mm}^{2}$ value calculated for the constitutively expressed glyceraldehyde phosphate dehydrogenase (GAPDH) gene which was also included in the template set.

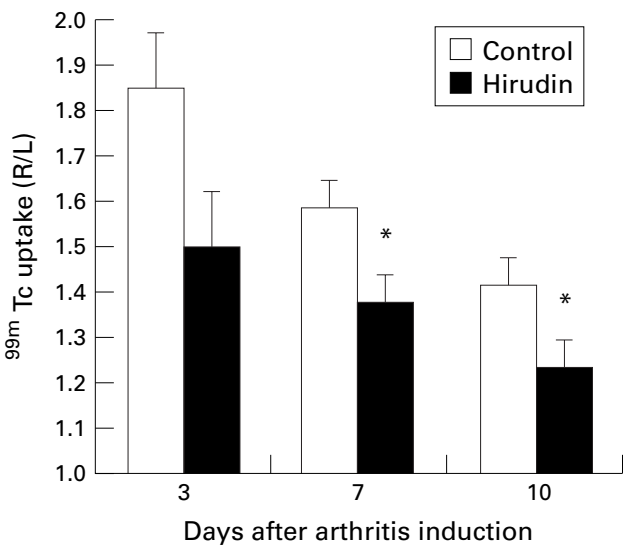

Figure 2 Time course of knee joint inflammation in hirudin treated mice with antigen induced arthritis. Foint inflammation was measured by external gamma counting of ${ }^{99 m}$ Tc uptake on days 3, 7, and 10 after antigen challenge into the right knee. Results are expressed as the ratio of ${ }^{99 m}$ Tc uptake in the right $(R)$ arthritic knee joint over the left (L) non-inflamed contralateral knee joint, a value higher than 1.1 indicating joint inflammation. For each time point the mean (SEM) of the ratios is shown. Control $(n=11)$, hirudin day $3(n=12)$, days 7 and $10(n=11)$. Statistical significance was tested by Student's $t$ test. The $p$ values were 0.108 (day 3); 0.028 (day 7); 0.035 (day 10). ${ }^{\star} p<0.05$ was considered significant. 
STATISTICAL ANALYSIS

The Wilcoxon/Kruskal-Wallis (rank sum test) for unpaired variables was used to compare differences between groups with non-Gaussian distribution. The unpaired Student's $t$ test was used to compare means for normally distributed values. A level of $p<0.05$ was considered significant.

\section{Results}

EFFICACY OF ANTICOAGULATION BY HIRUDIN IN MICE

In a pilot experiment (with six mice) we found that one daily subcutaneous injection of $200 \mu \mathrm{g}$ of hirudin led to prolonged aPTT and TT only for up to four hours (results not shown). On the basis of these preliminary results, we decided to treat mice with subcutaneous injections of hirudin every eight hours. To confirm that hirudin, given three times a day over 13 days (three days before and 10 days after AIA onset), was efficient, the aPTT, TT, and PT were measured at different times after the last subcutaneous injection of $200 \mu \mathrm{g}$ of hirudin. There was a significant prolongation of the aPTT and TT, which attenuated with time. An anticoagulant effect was observed at three hours after injection, with a return to normal coagulation times at five hours after injection (table 1). As already noted by others, ${ }^{18}$ no prolongation of the PT was seen with this treatment.

Inhibition of thrombin by hirudin was also documented by plasma TAT levels. Plasma TAT levels were reduced in hirudin treated mice, though this decrease reach significance only at 1.5 hours after the hirudin injection (see table 1).

ANTI-MBSA ANTIBODIES LEVELS IN HIRUDIN TREATED AND CONTROL MICE

To verify that hirudin treated mice generated an adequate immune response to $\mathrm{mBSA}$, antiBSA antibody levels were measured by ELISA

\section{Safranin}

\section{Fibrin immunostaining}
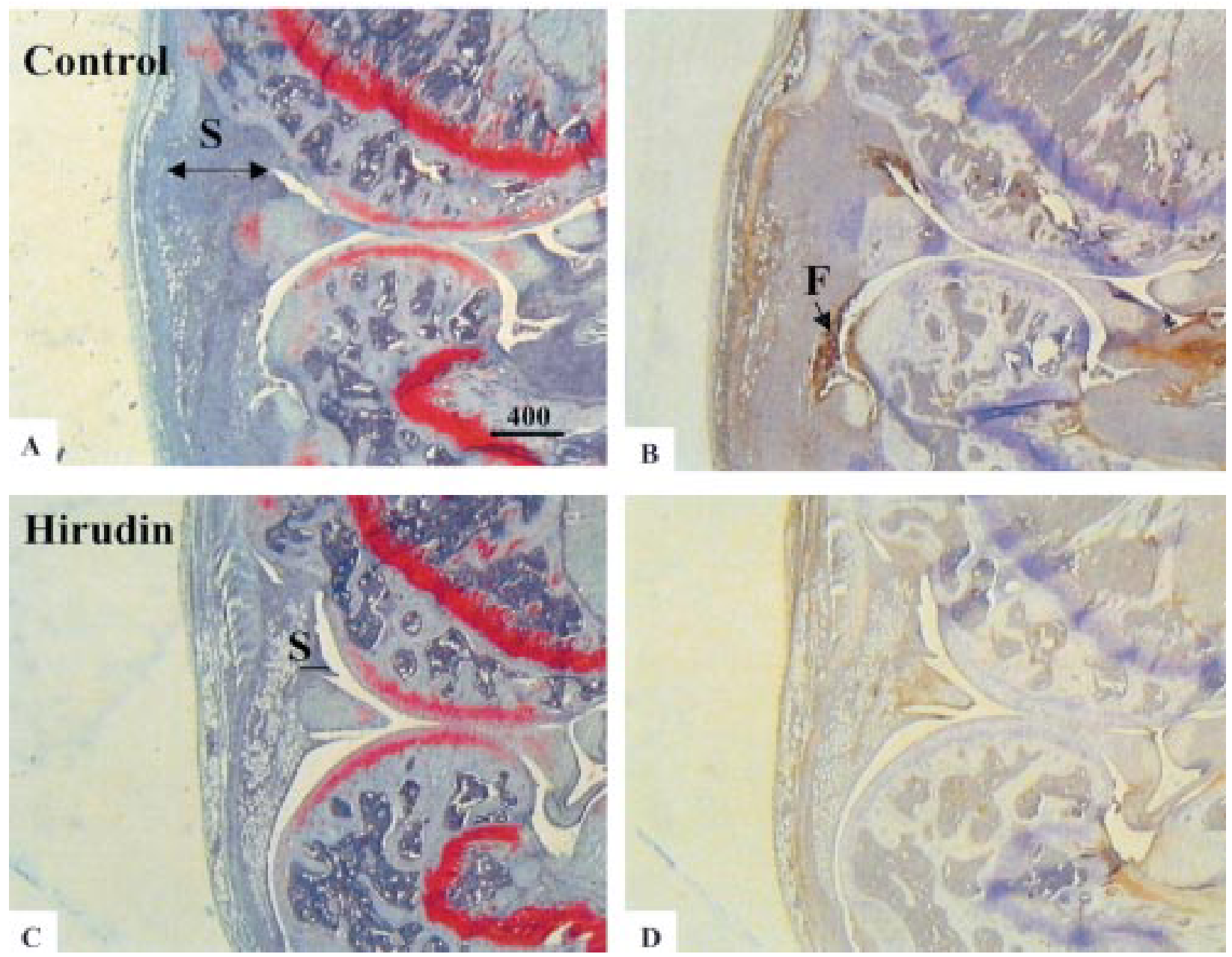

Figure 3 Histologies and immunohistologies of whole knee joint sections of control and of hirudin treated mice with antigen induced arthritis. Figures A and $C$ show safranin $O$ stained sections of arthritic knee joints at day 10 after arthritis induction. Note the difference of thickness of synovial membrane $(S)$ which is thicker in the control arthritic mice than in the hirudin treated ones. Figures $B$ and $C$ show fibrin(ogen) immunostaining (indicated by ( $F$ ) on Figure 3B) of adjacent sections. 
on day 10 after arthritis onset. No significant differences in antibody levels were seen between immunised mice treated with hirudin or PBS treated mice (fig 1).

\section{EFFECT OF HIRUDIN TREATMENT ON} TECHNETIUM UPTAKE IN AFFECTED KNEE JOINTS To explore whether the anticoagulation treatment had an effect on the course of AIA, we measured knee joint inflammation in control and hirudin treated mice by the ratio of ${ }^{99 \mathrm{~m}} \mathrm{Tc}$ uptake in the inflamed arthritic joint and that of the non-arthritic contralateral knee joint at different times up to day 10 (fig 2). In PBS treated animals, inflammation developed rapidly so that by day 3, the uptake ratio reached 1.85. Inflammation declined subsequently, and by day 10 , the uptake ratio was 1.4 . In hirudin treated mice, we observed an attenuation of the inflammatory response throughout the duration of the experiment (day 3: $17 \%$ decrease; days 7 and 10: $13 \%$ decrease). A significant difference in ${ }^{99 \mathrm{~m}} \mathrm{Tc}$ uptake was seen on days 7 and 10 in comparison with control animals.

\section{EFFECT OF HIRUDIN TREATMENT ON} HISTOLOGICAL FEATURES OF ARTHRITIS

We compared the histological features of arthritic knee joints from untreated control and hirudin treated mice at day 10 after arthritis
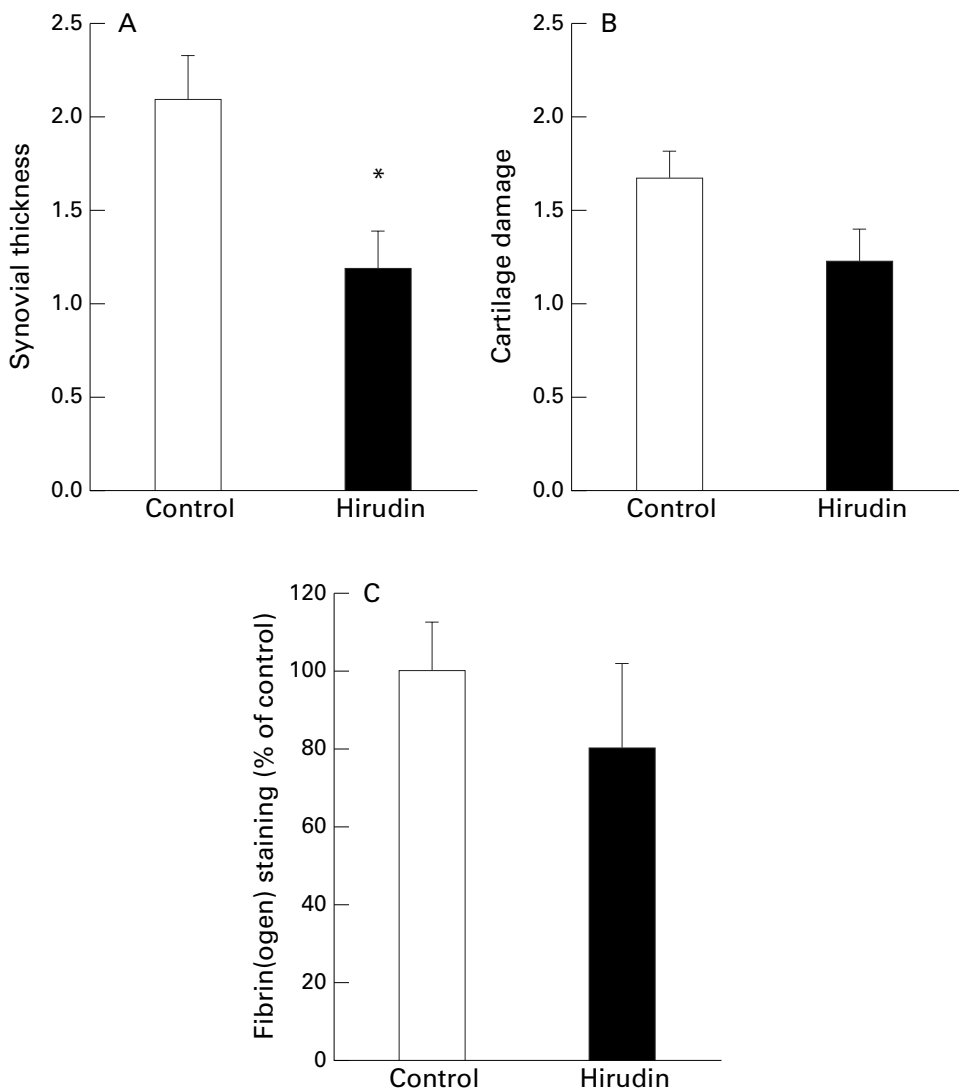

Figure 4 Histological grading and fibrin scoring of arthritic knee joints. Synovial thickness $(A)$ and cartilage damage $(B)$ were scored histologically using an arbitrary scale from 0 to 3. Fibrin deposition $(C)$ was scored in the synovial membrane using an arbitrary scale from 0 to 6 and expressed as a percentage of fibrin deposition (control $=100 \%$ ).

Results are expressed as means (SEM), control and hirudin treated mice, $n=11$ per group. Statistical significance was tested by Wilcoxon/Kruskal-Wallis tests (rank sums). ${ }^{*} p<0.05$ was considered significant. onset (figs 3A and C). In both groups some signs of synovitis were seen in all mBSA injected joints, which were absent in contralateral knees injected with PBS only (results not shown). In the untreated group, synovial membrane thickness (indicated by $\mathrm{S}$ on fig $3 \mathrm{~A}$ ) was greater than in the hirudin treated group (fig 3C). The effect of AIA on articular cartilage was also evaluated. Induction of arthritis led to a decrease in proteoglycan content in both groups, as shown by the partial loss of safranin $\mathrm{O}$ staining (figs $3 \mathrm{~A}$ and $\mathrm{C}$ ).

Semiquantitative scoring was performed on histological sections using a four point $(0-3)$ grading system to evaluate synovial thickness and cartilage damage. Each joint was scored by two independent assessors. The reduction in synovial thickness in hirudin treated animals at day 10 was statistically significant (fig 4A), but cartilage damage, though diminished, was not statistically different (fig 4B).

\section{EFFECT OF HIRUDIN TREATMENT ON FIBRIN}

DEPOSITION IN ARTHRITIC JOINTS

We wanted next to evaluate if hirudin treatment reduces intra-articular fibrin deposition in AIA. Fibrin content was analysed by fibrin immunohistochemistry - a brown colour indicating positivity (figs $3 \mathrm{~B}$ and $\mathrm{D}$ ) — and by visual scoring (fig 4C). The antibody specificity was shown by the absence of staining when sections were incubated with normal rabbit serum or when the polyclonal antibody was preincubated with an excess of purified murine fibrinogen (results not shown). In arthritic knee joints of untreated mice, fibrin was found in the synovium, the synovial fluid, and on the surface of the articular cartilage (fig 3B). Decreased amounts of fibrin were detected in hirudin treated mice (fig 3D). When immunohistological scoring was used, mice treated with hirudin showed a $20 \%$ reduction in the level of fibrin compared with non-treated animals, though this did not reach statistical significance.

EFFECT OF HIRUDIN TREATMENT ON IL1 $\beta$ MRNA To establish whether hirudin treatment might alter the pattern of inflammatory cytokine expression in the synovium we analysed, after 10 days of AIA, synovial mRNA expression of different molecules (interleukin $1 \beta$ (IL1 $\beta$ ); interleukin 1 receptor antagonist (IL1Ra); macrophage migration inhibitory factor (MIF)), by RNase protection (fig 5). In synovial tissues from non-arthritic knees, only MIF mRNA could be detected, whereas in arthritic knees, there was a marked induction of IL1 $\beta$ and IL1Ra mRNAs. Quantitative results were obtained by Phosphoimager analysis after normalisation by GAPDH mRNA levels. In hirudin treated mice, at day 10 of AIA, synovial IL1 $\beta$ mRNA levels were reduced by $20 \%$ compared with sham treated mice (sham $v$ hirudin, 100 (16)\% v 80 (13)\%, four mice per group, mean (SEM)), but this reduction did not reach significance. In the same conditions, IL1 Ra and MIF mRNA levels were unchanged (results not shown). 


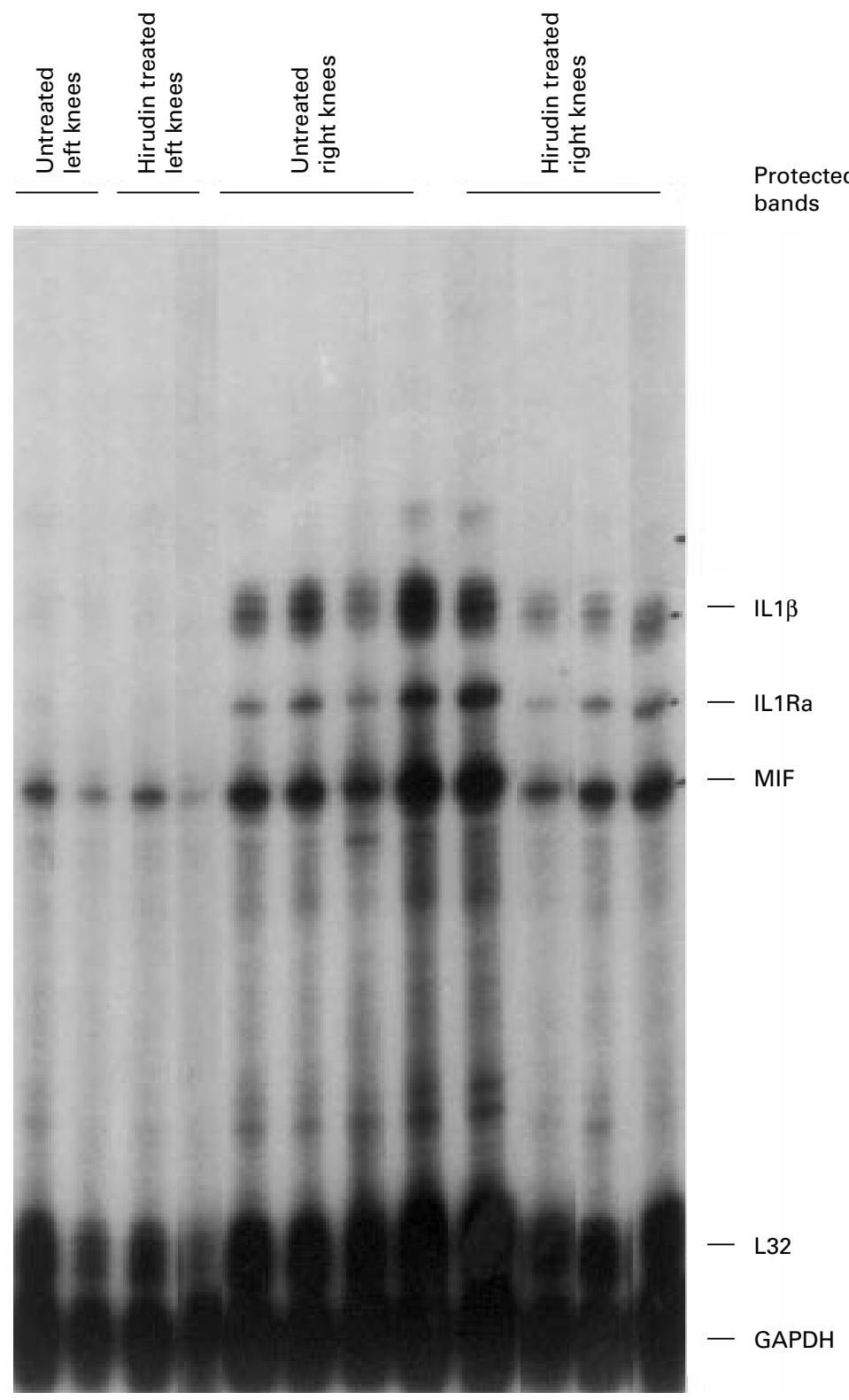

Figure 5 Synovial cytokine $m R N A$ levels in knee joints from untreated or hirudin treated mice. Total RNA was prepared from non-arthritic (left knee) or from arthritic (right knee) joints of untreated or hirudin treated mice at day 10 after induction of arthritis. Expression of different cytokine $m R N A$ s was analysed by RNase protection assay using a multiprobe set which included interleukin $1 \beta$ (IL1 $\beta$ ), IL1 receptor antagonist (IL1Ra), and macrophage migration inhibitory factor (MIF).

\section{Discussion}

In RA, fibrin deposition within the joint is prominent, suggesting that it may have a pathogenetic role in the disease. Based on our prior observations that mice deficient in urokinase showed more severe synovitis and more destructive arthritis during AIA, we proposed that increased fibrin deposition in these animals may have a deleterious effect on arthritis. As thrombin generation is essential for fibrin deposition, and also because thrombin receptor activation may mediate some of the inflammatory cellular responses found during AIA, we decided to investigate if thrombin inhibition might reduce synovial inflammation in this animal model of RA. We started hirudin treatment before the joint injection of mBSA to give the best chance of observing if hirudin can modulate joint inflammation.

The results of our experiments showed that hirudin did indeed significantly attenuate the severity of AIA, as measured by both ${ }^{99 \mathrm{~m}} \mathrm{Tc}$ uptake and synovial histology. We were able to exclude an effect of hirudin on the immune response to BSA, as plasma anti-BSA antibody titres were equivalent in the two groups of mice. In parallel with the reduction in synovitis, we also found a trend towards diminished synovial IL1 $\beta$ mRNA production in hirudin treated animals, further suggesting that the treatment attenuated the proinflammatory state within the knee

It has been previously reported that thrombin may also directly damage cartilage, as it induces proteoglycan release in vitro. ${ }^{23}$ In our study we found a trend, though not statistically significant, towards reduction of cartilage degradation in hirudin treated mice. The absence of a significant effect may be explained by the relatively insensitive histological grading system used to evaluate cartilage damage.

Intra-articular fibrin staining was reduced by hirudin treatment, though only by $20 \%$. This small reduction is most probably accounted for by the dosing schedule used in our study, which only provided partial anticoagulation during the period of study. For practical reasons, we chose to give hirudin to mice subcutaneously three times daily, as it was impossible to give it by continuous infusion (as in man). Overall, no adverse effects were seen, and no animals developed signs of spontaneous bleeding. Lepirudin, the form of hirudin given, has a half life of 0.8-1.4 hours in man when given subcutaneously, with a $\mathrm{C}_{\max }$ of $1.7-2.6$ hours. ${ }^{19}$ In our preliminary experiments we showed that after a $200 \mu \mathrm{g}$ dose an anticoagulant effect was seen three hours after subcutaneous injection, but was no longer evident at five hours. If it is assumed that an anticoagulant effect was present for up to four hours after each injection, the animals were therefore anticoagulated for only around 12 hours a day. We have also done pilots experiments using more conventional anticoagulants, such as antivitamin $\mathrm{K}$. In these experiments, anticoagulation was maintained over 24 hours, but some mice had severe bleeding problems. Nevertheless, in the non-bleeding mice we also obtained decreased synovial inflammation (as measured by ${ }^{99 \mathrm{~m}} \mathrm{Tc}$ uptake and synovial histology), thus reinforcing the linkage between anticoagulation and reduced joint inflammation.

Despite the partial anticoagulation induced by hirudin treatment, and the moderate reduction of intra-articular fibrin content, a clear reduction was seen in synovial inflammation. This suggests that hirudin may inhibit more than the coagulative function of thrombin. Thrombin can promote the chemotaxis of neutrophils and monocytes and their adhesion to endothelial cells. It can also induce mitogenesis of synoviocytes, ${ }^{2425}$ and can act on endothelial cells to increase vascular permeability and the synthesis of various proinflammatory molecules (see review ${ }^{16}$ ). These cellular events of thrombin are mediated by the PAR- 1 thrombin 
receptor. ${ }^{17}$ In arthritis, PAR-1 is abundantly expressed in inflamed rheumatoid synovial tissues. ${ }^{26}$ In this respect, it is interesting to note that a single injection of a low dose of thrombin can induce an inflammatory response in the injected rat $\mathrm{knee}^{16}$ or oedema in the injected rat hind paw. ${ }^{27}$ Moreover, thrombin receptoractivating peptides, which are synthetic peptides corresponding to the "tethered ligand" of PAR-1, mimicked the effect of thrombin in inducing paw oedema ${ }^{27}$ further underlining the importance of thrombin receptor activation in inflammation. The availability of PAR-1 deficient mice $^{28}$ will in the future allow a more precise investigation into these cellular actions of thrombin in vivo.

In conclusion, we have shown that thrombin inhibition by hirudin attenuates synovial inflammation and the histological changes of AIA. Although the roles of thrombin in synovial inflammation associated with AIA are not totally explained, the ability of thrombin to participate in both haemostatic and inflammatory responses suggests that selective and direct inhibition of thrombin by hirudin based reagents may represent an additional treatment strategy in RA.

We thank the haemostasis laboratory of the CHUV for their help in clotting time measurements. We are indebted to Dr Eric Kolodziesczyk for his continuous support in microscopy analysis.

This work was supported by a grant from the Fonds national suisse de la recherche scientifique (number 3200-051113.97), the Jean and Linette Warnery Foundation, and the Böni Foundation.

1 Firestein GS. Etiology and pathogenesis of rheumatoid arthritis. In: Kelley WN, Harris ED, Ruddy S, Sledge CB eds. Textbook of rheumatology. Philidelphia: Saunders, 1997:851-97.

2 Clemmensen I, Holund B, Andersen RB. Fibrin and fibronectin in rheumatoid synovial membrane and rheumatoid synovial fluid. Arthritis Rheum 1983;26:479-85.

3 Weinberg JB, Pippen AM, Greenberg CS. Extravascular fibrin formation and dissolution in synovial tissue of patients with osteoarthritis and rheumatoid arthritis. Arthritis Rheum 1991;34:996-1005.

4 Cicala C, Cirino G. Linkage between inflammation and coagulation: an update on the molecular basis of the crosstalk. Life Sci 1998;62:1817-24.

5 Zacharski LR, Brown FE, Memoli VA, Kisiel W, Kudryk BJ, Rousseau SM, et al. Pathways of coagulation activation in sousseau SM, et al. Pathways of coagulation activation in pathol 1992;63:155-62.

6 Nakano S, Ikata T, Kinoshita I, Kanematsu J, Yasuoka S. Characteristics of the protease activity in synovial fluid from patients with rheumatoid arthritis and osteoarthritis. Clin Exp Rheumatol 1999;17:161-70.

7 Carmassi F, de Negri F, Morale M, Song KY, Chung SI. Fibrin degradation in the synovial fluid of rheumatoid arthritis patients: a model for extravascular fibrinolysis. Semin Thromb Hemost 1996;22:489-96.
8 Jasani MK. Fibrin: metabolism, immunopathogenesis and significance in rheumatoid arthritis. In: Panayi GS, Johnson PM, eds. Immunopathogenesis of rheumatoid arthritis. Surrey, UK: Red Books, 1978:137-46.

9 Mapp PI, Grootveld MC, Blake DR. Hypoxia, oxidative tress and rheumatoid arthritis. Br Med Bull 1995;51:41936.

10 Dvorak HN, Senger DR, Dvorak AM, Harvey VS, McDonagh J. Regulation of extravascular coagulation by microvascular permeability. Science 1985;227:1059-61.

11 Senior RM, Skogen WF, Griffin GL, Wilner GD. Effects of fibrinogen derivatives upon the inflammatory response. Studies with human fibrinopeptide B. J Clin Invest 1986;77:1014-19.

12 Perez RL, Roman J. Fibrin enhances the expression of IL-1 beta by human peripheral blood mononuclear cells. Implications in pulmonary inflammation. J Immunol 1995;154: 1879-87.

13 Robson SC, Shephard EG, Kirsch RE. Fibrin degradation product $\mathrm{D}$-dimer induces the synthesis and release of biologically active IL-1 beta, IL-6 and plasminogen activator inhibitors from monocytes in vitro. $\mathrm{Br} \mathrm{J}$ Haematol 1994;86:322-6.

14 Qi J, Kreutzer DL. Fibrin activation of vascular endothelial cells. Induction of IL-8 expression. J Immunol 1995;155: $867-76$

15 Busso N, Péclat V, van Ness K, Kolodziesczyk E, Degen J, Bugge T, et al. Exacerbation of antigen-induced arthritis in urokinase-deficient mice. J Clin Invest 1998;102:41-50.

16 Morris R, Winyard PG, Blake DR, Morris CJ. Thrombin in inflammation and healing: relevance to rheumatoid arthritis. Ann Rheum Dis 1994;53:72-9.

17 Coughlin SR. Sol Sherry lecture in thrombosis: how thrombin "talks" to cells: molecular mechanisms and roles in vivo. Arterioscler Thromb Vasc Biol 1998;18:514-18.

18 Markwardt F. The development of hirudin as an antithrombotic drug. Thromb Res 1994;74:1-23.

19 Adkins JC, Wilde MI. Lepirudin. Biodrugs 1998;10:228-

20 Fareed J, Callas D, Hoppensteadt DA, Lewis BE, Bick RL, Walenga JM. Antithrombin agents as anticoagulants and antithrombotics: implications in drug development. Semin Hematol 1999; 36:42-56.

21 Brackertz D, Mitchell GF, Mackay IR. Antigen-induced arthritis in mice. I. Induction of arthritis in various strains of mice. Arthritis Rheum 1977;20:841-50.

22 Kruijsen MW, van den Berg WB, van de Putte LB, van den Broek WJ. Detection and quantification of experimental joint inflammation in mice by measurement of $99 \mathrm{mTc}-$ pertechnetate uptake. Agents Actions 1981;11:640-2.

23 Furmaniak-Kazmierczak E, Cooke TD, Manuel R, Scudamore A, Hoogendorn $\mathrm{H}$, Giles AR, et al. Studies of thrombin-induced proteoglycan release in the degradation of human and bovine cartilage. J Clin Invest 1994;94:47280.

24 Shin H, Nakajima T, Kitajima I, Shigeta K, Abeyama K, Imamura $\mathrm{T}$, et al. Thrombin receptor-mediated synovial proliferation in patients with rheumatoid arthritis. Clin Immunol Immunopathol 1995;76:225-33.

25 Ohba T, Takase Y, Ohhara M, Kasukawa R. Thrombin in the synovial fluid of patients with rheumatoid arthritis mediates proliferation of synovial fibroblast-like cells by induction of platelet derived growth factor. J Rheumatol 1996;23:1505-11.

26 Morris R, Winyard PG, Brass LF, Blake DR, Morris CJ. Thrombin receptor expression in rheumatoid and osteoarthritic synovial tissue. Ann Rheum Dis 1996;55:841-3.

27 Cirino G, Cicala C, Bucci MR, Sorrentino L, Maraganore JM, Stone SR. Thrombin functions as an inflammatory mediator through activation of its receptor. J Exp Med mediator through

28 Connolly AJ, Ishihara H, Kahn ML, Farese RV Jr, Coughlin SR. Role of the thrombin receptor in development and evidence for a second receptor. Nature 1996;381:516-19. 